Журнал«Герспективита іновації науки»

(Серія«Герагогіка», Серія«Гцихологія», Серія«Медицинв»

№2(7) 2022

УДК: 378.091.011.3-051:796:613

https://doi.org/10.52058/2786-4952-2022-2(7)-110-118

Анастасова Ольга Юріївна кандидат педагогічних наук, доцент кафедри фізичного виховання, Бердянський державний педагогічний університет, вул. Шмідта, 4, м. Бердянськ, 71100, тел.: (066) 80-62-672, https://orcid.org/0000-0002-8966-8474

\title{
ЗДОРОВ'ЯЗБЕРЕЖУВАЛЬНА СКЛАДОВА У ЗМІСТІ ПІДГОТОВКИ МАЙБУТНІХ УЧИТЕЛІВ ФІЗИЧНОЇ КУЛЬТУРИ
}

Анотація. Численні наукові дослідження свідчать, що сучасні інноваційні зміни та вхід України до освітнього Європейського простору зумовили нові вимоги до компетентності майбутніх учителів фізичної культури. Підготовка випускників у закладах вищої освіти повинна повністю забезпечувати формування готовності майбутніх учителів фізичної культури до професійнопедагогічної діяльності, самовдосконалення та саморозвитку. Перед закладом вищої освіти особливо гостро постала проблема підготовки компетентних, відповідальних, конкурентоспроможних на ринку праці фахівців фізичної культури, здатних мобільно реагувати на зміни у фізкультурно-освітньому просторі.

У статті розглядається проблема сьогодення, що спонукає змінювати вимоги до стану здоров'я і рівня фізичної підготовленості школярів та студентської молоді. На основі аналізу валеологічної, психолого-педагогічної літератури уточнено сутність поняття "підготовка майбутніх учителів фізичної культури”, яка розглядається нами як алгоритмізований суб'єкт-суб'єктний цілеспрямований педагогічний процес, спрямований на отримання фундаментальних знань у галузі фізичної культури та формування умінь i навичок їх використання у освітньому процесі загальноосвітньої школи.

Охарактеризовано навчальну дисципліну “Теорія та методика фізичного виховання" як складову освітньої програми підготовки здобувачів вищої освіти за спеціальністю 014.11 Середня освіта (Фізична культура) та впроваджено здоров'язбережувальної складової до змісту підготовки майбутніх учителів фізичної культури у закладах вищої освіти. Мета дисципліни „Теорія та методика фізичного виховання" - озброїти здобувачів вищої освіти глибокими теоретичними і практичними основами фізичного виховання і спорту, а також навчити їх практично впроваджувати здоров'язбережувальні складові у майбутній професійній діяльності.

У ході нашого дослідження дійшли висновку, що вивчення дисципліни „Теорія та методика фізичного виховання” у процесі фахової підготовки майбутніх учителів фізичної культури сприяє підготовці висококваліфікованих фахівців, здатних виконувати багатофункціональну професійну діяльність у 
закладах вищої освіти, формувати традиції і культуру здорового способу життя підростаючого покоління України.

У науковій статті доведено актуальність і доцільність обраної проблеми дослідження.

Ключові слова: підготовка, майбутній учитель фізичної культури, заклад вищої освіти, здоров'язбережувальна складова.

Anastasova Olha Yuriivna Candidate of pedagogical sciences, Associate Professor, Berdiansk State Pedagogical University, Schmidt St., 4, Berdiansk, 71100, tel.: (066) 80-62-672, https://orcid.org/0000-0002-8966-8474

\section{HEALTH CARE COMPONENT IN THE CONTENT OF TRAINING OF FUTURE TEACHERS OF PHYSICAL CULTURE}

Abstract. Numerous scientific studies show that modern innovative changes and Ukraine's entry into the European educational space have led to new requirements for the competence of future physical education teachers. The training of graduates in higher education institutions should fully ensure the formation of readiness of future teachers of physical culture for professional and pedagogical activities, selfimprovement and self-development. The problem of training competent, responsible, competitive in the labor market specialists in physical culture, able to respond mobile to changes in the physical culture and educational space, is particularly acute for higher education institutions.

The article examines the problem of today, which encourages to change the requirements for the state of health and level of physical fitness of schoolchildren and students. Based on the analysis of valeological, psychological and pedagogical literature, the essence of the concept of "training of future teachers of physical culture" is clarified their use in the educational process of secondary school.

The discipline "Theory and Methods of Physical Education" is characterized as part of the educational program for higher education in specialty 014.11 Secondary Education (Physical Education) and introduced a health component to the content of training future physical education teachers in higher education. The purpose of the discipline "Theory and Methods of Physical Education" is to equip higher education students with deep theoretical and practical foundations of physical education and sports, as well as teach them to implement health components in future professional activities.

In the course of our research we concluded that the study of the discipline "Theory and Methods of Physical Education" in the process of professional training of future physical education teachers contributes to the training of highly qualified professionals capable of performing multifunctional professional activities in higher education institutions.

The scientific article proves the relevance and feasibility of the chosen research problem. 
Журнал«Герспективитаінновації наукиљ

(Серія«Гедагогіка», Серія«Гцихологія», Серія«Медицинв»

№2(7) 2022

Keywords: training, future physical education teacher, higher education institution, health component.

Постановка проблеми. Стан здоров'я і фізичного розвитку школярів та студентської молоді викликає сьогодні цілком зрозумілу тривогу в суспільстві. Погіршення стану здоров'я молодого покоління є результатом впливу не тільки соціально-економічних і екологічних чинників, а й наслідком серйозних недоліків в організації фізичного виховання дітей. Тому останніми роками система підготовки майбутніх учителів фізичної культури у закладах вищої освіти піддавалася обгрунтованій критиці.

Перед системою вищої педагогічної освіти, яка покликана реагувати на потреби суспільства, актуалізуються завдання щодо підготовки нової генерації майбутніх учителів фізичної культури, здатних здійснювати оздоровчо-виховну роботу на високому професійному рівні в умовах Нової української школи, та забезпечувати вирішення низки проблем щодо залучення дітей і студентської молоді до занять фізичною культурою та формування у них здорового способу життя $[4,6,8,9]$.

Після входження України до єдиного європейського освітнього простору зростають вимоги до якості підготовки майбутніх фахівців сфери фізичної культури і спорту, до рівня їх професійних компетентностей та готовності реалізовувати набуті компетентності у майбутній педагогічній діяльності в закладах загальної середньої освіти, здатних володіти фаховими знаннями, вміннями та навичками, готових до постійного професійного зростання, соціальної та професійної мобільності, ефективної роботи за фахом на рівні світових стандартів і творчо підходити до вирішення неординарних питань, тобто компетентних фахівців нового покоління, які готові до здійснення якісних фізкультурно-оздоровчих послуг в умовах концепції Нової української школи.

Аналіз останніх досліджень і публікацій. У психолого-педагогічній літературі проблема професійної підготовки майбутніх учителів фізичної культури має багатоаспектне теоретичне висвітлення. Концептуальні засади підготовки майбутніх фахівців фізичного виховання та спорту висвітлено в багатьох працях вітчизняних дослідників.

Науковці (О. Ажиппо, О. Базильчук, Н. Бєлікова, М. Василенко, М. Данилевич, Є. Захаріна, Л. Іванова, А. Конох, Ю. Лянной, Є. Приступа, Л. Сущенко, О. Тимошенко та ін.) вказують, що головна мета освітньої політики в напрямі модернізації вищої фізкультурної освіти полягає в забезпеченні якості, фундаментальності, престижності, відповідності актуальним і перспективним потребам особистості та суспільства щодо інноваційного оновлення освітньої галузі в цілому й науково обгрунтованих змін змісту, форм і методів навчання майбутніх фізкультурних кадрів у закладах вищої освіти [5, С. 2].

Науковий інтерес для дослідження становили праці, у яких розкриваються питання підготовки майбутніх учителів фізичної культури підготовки майбутніх учителів фізичної культури до здоров'язбережувальної професійної діяльності 
(М. Верховська [1]; П. Джуринський [2]; К. Дроздова [3]; В. Дручик, [4]; Г. Остапенко, [7] та ін.).

Мета статті - охарактеризувати навчальну дисципліну “Теорія та методика фізичного виховання" як складову освітньої програми підготовки здобувачів вищої освіти за спеціальністю 014.11 Середня освіта (Фізична культура); впровадження здоров'язбережувальної складової до змісту підготовки майбутніх учителів фізичної культури у закладах вищої освіти.

Виклад основного матеріалу. Проведений нами аналіз психологопедагогічної літератури дає підстави стверджувати, що на сьогодні не існує єдиного погляду на розуміння проблеми професійної підготовки майбутніх учителів фізичної культури.

У зв’язку з тим, що у нашому дослідженні будемо користуватися поняттям “підготовка майбутніх учителів фізичної культури”, на підставі глибокого аналізу психолого-педагогічної літератури, ми дотримуємося визначення, яке подає український науковець Л. Сущенко.

Вчена тлумачить підготовку майбутніх фахівців фізичного виховання та спорту як "процес, який характеризує технологічно обгрунтовані засади вищих навчальних закладів країни надати особистості такого рівня професіоналізму, завдяки якому вона стане конкурентоспроможною на ринках праці, буде самостійно організовувати фізичне виховання різних верств населення регіону й успішно працювати в усіх ланках спортивного руху" [8, С. 28].

На основі аналізу наукової літератури підготовка майбутніх учителів фізичної культури розглядається нами як алгоритмізований суб'єкт-суб'єктний цілеспрямований педагогічний процес, спрямований на отримання фундаментальних знань у галузі фізичної культури та формування умінь i навичок їх використання у освітньому процесі загальноосвітньої школи.

Основна мета професійно-педагогічної підготовки у закладах вищої освіти підготовка кваліфікованого вчителя, зокрема спеціаліста 3 фізичної культури, конкурентноздатного на ринку праці, компетентного, відповідального, такого, який вільно володіє своєю професією, здатного до ефективної роботи за фахом, готового до постійного професійного зростання, соціальної і професійної мобільності.

Дисципліна “Теорія та методика фізичного виховання" є обов'язковою навчальною дисципліною нормативної частини циклу професійної та практичної підготовки здобувачів вищої освіти за спеціальністю 014.11 Середня освіта (Фізична культура).

3 метою підготовки майбутніх учителів фізичної культури до впровадження здоров'яформуючих технологій у навчально-виховному процесі загальноосвітньої школи нами було включено змістові модулі у робочу програму дисципліни “Теорія та методика фізичного виховання", яка розроблена старшим викладачем кафедри теорії та методики фізичного виховання Бердянського державного педагогічного університету С. Данило.

Мета дисципліни „Теорія та методика фізичного виховання” - озброїти здобувачів вищої освіти глибокими теоретичними і практичними основами 
фізичного виховання і спорту, а також навчити їх практично впроваджувати здоров’язбережувальні складові у майбутній професійній діяльності.

Досконало проаналізувавши навчальну програму 3 дисципліни „Теорія та методика фізичного виховання", нами розширено теми змістових модулів.

Навчальна програма дисципліни „,Теорія та методика фізичного виховання” складається 3 таких змістових модулів: теорії та методики фізичного виховання як наукова i навчальна дисципліна; основи системи фізичного виховання; специфічні засоби фізичного виховання; допоміжні засоби фізичного виховання; методи та принципи фізичного виховання; основи навчання руховим вмінням та навичкам; основи методики розвитку сили; основи методики розвитку швидкості; основи методики розвитку витривалості; основи методики розвитку спритності та гнучкості; соціально-педагогічне значення та завдання фізичного виховання дітей шкільного віку; фізичне виховання дітей шкільного віку; урочні форми занять; позаурочні форми занять; технологія планування, його функції та зміст; організація навчально-дослідної роботи студентів.

Дисципліна „Теорія та методика фізичного виховання” відіграє важливу роль у підготовці майбутніх учителів фізичної культури, і від змісту та якості викладання цього предмета багато в чому залежить готовність майбутніх учителів фізичного культури до впровадження здоров'язбрежувальних технологій у закладах загальної середньої освіти.

При вивчення I змістового модулю передбачало формування у майбутніх учителів фізичної культури розуміння змісту фізичного виховання з позиції оздоровчого значення фізичного виховання для формування здоров'я в усіх його аспектах.

Змістовий модуль II містить такі теми: „Специфічні засоби фізичного виховання”, „, Допоміжні засоби фізичного виховання”.

Отже, при вивченні теми “Допоміжні засоби фізичного виховання" розширювалося коло питань щодо розкриття їхньої сутності i значення у формуванні культури здоров'я школярів.

До II змістового модулю ми включили тему “Вплив природних сил i гігієнічних факторів на здоров'я школярів", знання з даної теми відіграють значну роль у формуванні культури здоров'я школярів і студентів. Дана тема розкриває питання: гігієна фізичного виховання дітей. Методика гігієнічної оцінки уроку фізичної культури. Гігієнічні вимоги до місць проведення занять фізичною культурою. Гігієнічні вимоги до організації харчування дітей. Фактори та умови навколишнього середовища, що впливають на формування здоров’я дітей. Природні сили як самостійні засоби оздоровлення. Поняття загартування. Основні правила і прийоми загартування.

Змістовий модуль III складається з теми: „Методи та принципи фізичного виховання".

У змістовий модуль III нами додано таку тему: “Механізми оздоровчого впливу фізичних вправ на організм людини”, яка включає питання: оздоровчий вплив фізичних вправ на опорно-руховий апарат, оздоровчий ефект фізичних 
вправ на серцево-судинну, м'язову, дихальну системи організму, поняття гіподинамії. Фактори, які характеризують оздоровчу ефективність впливу фізичних вправ: санітарно-гігієнічні, метеорологічні, матеріальні, комплексний вплив всіх засобів фізичного виховання.

Змістовий модуль $\mathrm{V}$ розкриває такі теми: „Основи методики розвитку сили”, „Основи методики розвитку швидкості”.

Змістовий модуль VI містить такі теми: „Основи методики розвитку витривалості”, „, Основи методики розвитку спритності та гнучкості”.

В змістові модулі нами впроваджено такі теми: “Особливості оздоровчої спрямованості розвитку гнучкості", “Особливості оздоровчої спрямованості розвиту сили”, “Особливості оздоровчої спрямованості розвитку витривалості”.

Тема “Особливості оздоровчої спрямованості розвитку гнучкості” містить такі питання: характеристика оздоровчої гімнастики - стретчинга. Оздоровчий вплив стретчингу на опорно-руховий апарат, нервову та м'язові системи. Причини погіршення прояву гнучкості. Визначення функціонального стану хребта і суглобів за допомогою функціонально-рухових тестів. Характеристика комплексів вправ на розвиток гнучкості: на поставу, комплекс вправ для пальців, для шийного відділу хребта, вправи для хребта, вправи для кульшових, гомілково-стопному суглобах.

Тема “Особливості оздоровчої спрямованості розвиту сили” розкриває такі питання: врахування навантаження, кількості повторень вправ; інтенсивності; чергування роботи і відпочинку. Розвиток основних м'язових груп: оздоровчі вправи $з$ протидією рук для розвитку сили м'язів шиї. Характеристика вправ м'язів рук i плечового поясу i опорно-рухового апарату. Самоконтроль. Оптимізація навантаження під час виконання силових вправ.

Тема “Особливості оздоровчої спрямованості розвитку витривалості” розкриває такі питання: характеристика вправ аеробного спрямування. Методичні рекомендації до виконання циклічних вправ загальної витривалості. Оздоровчі програми аеробного спрямування. Визначення оптимальної ЧСС під час занять оздоровчої спрямованості.

Змістовий модуль VII містить тему: „Соціально-педагогічне значення та завдання фізичного виховання дітей шкільного віку”.

Тему „Соціально-педагогічне значення та завдання фізичного виховання дітей шкільного віку" ми намагалися зорієнтувати таким чином, щоб наблизити до майбутньої професійної діяльності майбутніх учителів фізичної культури, ураховуючи іiі сучасні особливості й специфіку в контексті виховання учнів Нової української школи.

До VII змістового модулю ми додали тему “Модель навчального закладу Школа сприяння здоров'ю”. Тема включає такі питання: цілі та завдання школи сприяння здоров'ю. Характеристика підсистем: управлінської, дидактичної, виховної, науково-методичної, громадсько-педагогічної. Зміст соціальнопсихологічної, медико-валеологічної служби та інформаційно-методичне забезпечення. 
В змістовий модуль VIII “Фізичне виховання дітей шкільного віку” нами було введено тему: “Оптимізація навантаження на уроках фізичної культури 3 оздоровчим спрямуванням", яка містить такі питання: поняття “Фізичне навантаження”, характеристика інтенсивності та обсягу навантаження. Прийоми регулювання навантаження. Характеристика інтегрального показнику стану організму. Методики вивчення ЧСС на уроках фізичної культури з оздоровчим спрямуванням. Показники перевтоми. Загальна щільність уроку. Характеристика моторної щільності уроку.

Змістовий модуль X містить тему: „Позаурочні форми занять”.

Важливе значення у змісті даної дисципліни відіграє впроваджена нами тема “Фізкультурно-оздоровча робота у навчально-виховному процесі загальноосвітньої школи".

Тема "Фізкультурно-оздоровчі заходи" розкриває такі питання: сутність фізкультурно-оздоровчої роботи з учнями загальноосвітніх навчальних закладів. Фізкультурно-оздоровчі заходи у режимі навчального дня (гімнастика до занять, фізкультхвилинки на загальних уроках, рухливі перерви, перерва “здоров'я”, “година рухової активності” (форма роботи групи продовженого дня) та позакласні фізкультурно-оздоровчі заходи (фізкультурно-оздоровчі свята, спортивно-масові заходи). Методика проведення фізкультурно-оздоровчих заходів в режимі навчального дня. Методичні рекомендації щодо проведення фізкультурно-оздоровчих свят та спортивно-масових заходів у загальноосвітніх навчальних закладах.

Висновки. В ході нашого дослідження доведено, що майбутні учителі фізичної культури при вивченні дисципліни „Теорія та методика фізичного виховання" здобувають необхідну теоретико-методичну підготовку щодо формування, збереження й зміцнення здоров'я школярів в усіх його аспектах, яка дозволяє на якісно новому рівні організовувати заняття з фізичної культури в закладах загальної середньої освіти.

Перспективи подальших досліджень полягатимуть у оцінці готовності майбутніх учителів фізичної культури до впровадження здоров'язбережувальних технологій в закладах загальної середньої освіти.

\section{Лimepamypa:}

1. Верховська М. В. Готовність учителя фізичної культури до використання фізкультурно-оздоровчих технологій у роботі 3 учнями загальноосвітніх навчальних закладів як педагогічна проблема / М. В. Верховська // Педагогіка формування творчої особистості у вищій і загальноосвітній школах : зб. наук. праць / редкол. : Т. І. Сущенко (голов. ред.) [та ін.]. - Запоріжжя, 2014. - Вип. 34 (87). - С. 405-412.

2. Джуринський П. Б. Теоретичні і методичні засади підготовки майбутніх учителів фізичної культури до здоров'язбережувальної професійної діяльності : дис. ... д-ра пед. наук : 13.00.04 / ДЗ "ПНПУ ім. К. Д. Ушинського. Одеса, 2013. - 559 с.

3. Дроздова К. В. Підготовка майбутніх учителів фізичного виховання до формування здоров'язбережувальних навичок і вмінь у молодших школярів. Наука і освіта. 2015. - № 9. C. $45-50$. 
4. Дручик В. Д. Підготовка майбутніх учителів фізичної культури до впровадження здоров'язбережувальних технологій у старшій школі : дис. ... канд. пед. наук : 13.00 .04 / Акад. рекреаційних технологій і права. Київ, 2017. - 172 с.

5. Дутчак Ю. В. Система забезпечення якості професійної підготовки майбутніх магістрів середньої освіти з фізичної культури : автореф. дис. ... док. пед. наук : 13.00 .04 / Ю. В. Дутчак. - Київ, 2021. - 40 с.

6. Карасєвич С. А. Підготовка майбутніх учителів фізичної культури до фізкультурноспортивної діяльності у закладах загальної середньої освіти : монографія / С. А. Карасєвич ; Міністерство освіти і науки України ; Уманський держ. пед. унів-т імені Павла Тичини. Умань : ВПЦ “Візаві”, 2018. - 204 с. - С. 6.

7. Остапенко Г. О. Формування готовності майбутніх учителів фізичної культури до організації здоров'язбережувального освітнього середовища загальноосвітньої школи : автореф. дис. ... канд. пед. наук: 13.00.04 / Г. О. Остапенко ; Київ. ун-т ім. Б. Грінченка. - К., 2013. - 20 с.

8. Сущенко Л. П. Професійна підготовка майбутніх фахівців фізичного виховання та спорту (теоретико-методологічний аспект) : монографія / Л. П. Сущенко. - Запоріжжя : Запорізький державний університет, 2003. - 442 с.

9. Самсутіна Н. М. Методичні засади формування професійних функціональних компетентностей майбутніх учителів фізичної культури : монографія / Н. М. Самсутіна ; Міністерство освіти і науки України ; Бердянський державний педагогічний університет Бердянськ : ФО-П Ткачук О. В., 2014. - 192 с.

\section{References:}

1. Verkhovs'ka M. V. (2014). Ghotovnistj uchytelja fizychnoji kuljtury do vykorystannja fizkuljturno-ozdorovchykh tekhnologhij u roboti $\mathrm{z}$ uchnjamy zaghaljnoosvitnykh navchaljnykh zakladiv jak pedaghoghichna problema [Readiness of a physical education teacher to use physical culture and health technologies in working with students of secondary schools as a pedagogical problem]. Pedaghoghika formuvannja tvorchoji osobystosti u vyshhij i zaghaljnoosvitnij shkolakh Pedagogy of creative personality formation in higher and general education schools, vol. 34 (87), 405-412 [In Ukrainian].

2. Dzhurynsjkyj P. B. (2013). Teoretychni i metodychni zasady pidghotovky majbutnikh uchyteliv fizychnoji kuljtury do zdorov'jazberezhuvaljnoji profesijnoji dijaljnosti [Theoretical and methodical bases of preparation of future teachers of physical culture for health-preserving professional activity]. Doktor's thesis. Odesa [In Ukrainian].

3. Drozdova K. V. (2015). Pidghotovka majbutnikh uchyteliv fizychnogho vykhovannja do formuvannja zdorov'jazberezhuvaljnykh navychok i vminj u molodshykh shkoljariv [Preparation of future teachers of physical education for the formation of health skills and abilities in junior high school students]. Nauka i osvita. no. 9, pp. 45-50. [In Ukrainian].

4. Druchyk V. D. (2017). Pidghotovka majbutnikh uchyteliv fizychnoji kuljtury do vprovadzhennja zdorov'jazberezhuvaljnykh tekhnologhij u starshij shkoli [Preparing future physical education teachers for the introduction of health technologies in high school]. Candidate's thesis. Kyjiv [In Ukrainian].

5. Dutchak YU. V. (2021). Systema zabezpechennja jakosti profesijnoji pidghotovky majbutnikh maghistriv serednjoji osvity $\mathrm{z}$ fizychnoji kuljtury [Quality assurance system for professional training of future masters of secondary education in physical culture]. Extended abstract of Doctor's thesis. Kyjiv [In Ukrainian].

6. Karasyevych S. A. (2018). Pidghotovka majbutnikh uchyteliv fizychnoji kuljtury do fizkuljturnosportyvnoji dijaljnosti u zakladakh zaghaljnoji serednjoji osvity [Preparation of future teachers of physical culture for physical culture and sports activities in general secondary education institutions]. S. A. Karasyevych. Umanj : VPC "Vizavi” [In Ukrainian]. 
7. Ostapenko H. O. (2013). Formuvannja ghotovnosti majbutnikh uchyteliv fizychnoji kuljtury do orghanizaciji zdorov'jazberezhuvaljnogho osvitnjogho seredovyshha zaghaljnoosvitnjoji shkoly [Forming the readiness of future physical education teachers to organize a healthy educational environment of secondary school]. Extended abstract of candidate's thesis. Kyjiv [In Ukrainian].

8. Sushchenko L. P. (2003). Profesijna pidghotovka majbutnikh fakhivciv fizychnogho vykhovannja ta sportu (teoretyko-metodologhichnyj aspekt) [Professional training of future specialists in physical education and sports (theoretical and methodological aspect)]. L. P. Sushchenko. Zaporizhzhja : Zaporizjkyj derzhavnyj universytet [In Ukrainian].

9. Samsutina (2014). Metodychni zasady formuvannja profesijnykh funkcionaljnykh kompetentnostej majbutnikh uchyteliv fizychnoji kuljtury [Methodical bases of formation of professional functional competences of future teachers of physical culture]. N. M. Samsutina. Berdyans'k : FO-P Tkachuk O.V [In Ukrainian]. 